\title{
RATIO LEGIS OF THE CONSTITUTIONAL COURT DECISION ABOUT IMPEACHMENT: IS IT FINAL AND BINDING?
}

\author{
Khamim Muhammad Ma'rifatulloh, Sudarsono, Herman Suryokumoro \\ Master of Law, Postgraduate Program, University of Brawijaya \\ Jl. MT. Haryono No 169 Malang, East Java, Indonesia \\ E-mail: hamimmuhammadm@gmail.com
}

\begin{abstract}
Arrangement of the final and binding legal force the decisions of the Constitutional Court's impeachment not previously regulated in legislation. After PMK No 21 Year 21 Year 2009 paragraph (5) is issued, it also raises legal problems related to its material content. The formulation of the research problem is what ratio legislation Constitutional Court No. 21 of 2009 Article 19 Paragraph (5) About Impeachment. This research is a normative juridical approach with a statutory approach, a conceptual approach. The results of this study are to fill in the gaps or incomplete arrangements for the final nature and tie the decisions of the Constitutional Court's impeachment which were previously not in the legislation.
\end{abstract}

\section{Keywords: Final; Binding; Constitutional Court; Impeachment}

\section{A. INTRODUCTION}

Article 1 paragraph (3) of the 1945 Constitution of the Republic of Indonesia states "that the Indonesian state is a state of law". Simply put, Moh. Mahfud MD defines a state of law as a state whose administration of power is based on law, where the power to run the government is based on the rule of law (rule of law) and aims to carry out legal order and provide guidance on life for the community. ${ }^{1}$

Amendments to the Constitution of the Republic of Indonesia in 1945 formed a new institution in the part of the judicial authority. A special authority is attached which is one form of judicial control in the context of a system of checks and balances between branches of government power. In Article 24 paragraph (2) of the 1945 Constitution of the Republic of Indonesia states: "Judicial power is exercised by a Supreme Court and a body within the general court, religious court, military court, administrative court, and by a Constitutional Court."

Prof. Dr. Jimly Asshiddiqie explained that: "In the context of constitutional matters, the Constitutional Court was constructed as the guardian of the constitution that functions to uphold constitutional justice in the midst of people's lives. The Constitutional Court has the

\footnotetext{
${ }^{1}$ Mahfud MD , Hukum dan Pilar-Pilar Demokrasi, (Gama Media, Yogyakarta) 1999, p. 126
} 
duty to encourage and ensure that the constitution is respected and implemented by all components of the state in a consistent and responsible manner. Amid the weaknesses of the existing constitutional system, the Constitutional Court acts as an interpreter so that the spirit of the constitution is always alive and colors the sustainability of the state and society." ${ }^{2}$ The Constitutional Court was formed to guarantee the constitution as the highest law so that it can be upheld, so that the Constitutional Court is called the guardian of the constitution. ${ }^{3}$

The position of the Constitutional Court is on the same level as the Supreme Court as an independent judiciary ${ }^{4}$ in the Indonesian constitutional system. The Constitutional Court is also called the Sole Interpreter of the Constitution, because in exercising its authority, besides examining the law against the constitution. The Constitutional Court interprets the constitution. As a single constitutional interpreter, many matters in the trial have an effect on other powers in a face to face position, especially against the legislative body where the product is reviewed. ${ }^{5}$

The Constitutional Court has the function and duty as a protector of the constitution and as a function of guarding the constitution, so that it is implemented and respected by both the administrators of state power and citizens. The Constitutional Court was also asked to be the final interpreter of the constitution. Conceptually, the idea of establishing a Constitutional Court is to hold judiciary to uphold law and justice. Passing the first and last level of the decision which is final in terms of testing the law against the 1945 Constitution, and other authorities they have. ${ }^{6}$

The Constitutional Court of the Republic of Indonesia has five authorities and one obligation. The Basic Law outlines the authority of the Constitutional Court, namely (1) examining the law against the Constitution, (2) deciding on disputes over the authority of state institutions whose authority is granted by the Constitution, (3) deciding upon the dissolution of political parties, and (4) decide upon disputes about the results of general elections. and the Constitutional Court has one obligation which is to give a decision on the opinion of the House of Representatives regarding alleged violations by the President and / or Vice President according to the Basic Law.

Article 10 of the Constitutional Court Law specifically regulates the authority of the Constitutional Court, one of which is that the Constitutional Court is obliged to give a

\footnotetext{
${ }^{2}$ Maruarar Siahaan, Hukum Acara Mahkamah Konstitusi Republik Indonesia (Sinar Grafika: Jakarta) 2012 p. 8

${ }^{3}$ Nanang Sri Darmadi, Kedudukan Dan Wewenang Mahkamah Konstitusi Dalam Sistem Hukum Ketatanegaraan Indonesia, (Online) dalam Jurnal Hukum Vol XXVI, No. 2, Agustus 2011

${ }^{4}$ Miftakhul Huda, "Ultra Petita” dalam Pengujian Undang-Undang, (Online)dalam Jurnal Konstitusi Volume 4 Nomor 3, Mahkamah Konstitusi Republik Indonesia, Jakarta, September 2007, p. 144.

5 Sholahuddin Al-Fatih, Model Pengujian Peraturan Perundang-undangan Satu Atap Melalui Mahkamah Konstitusi, Legality: Jurnal Ilmiah Hukum, Volume 25 Nomor 2, 2017, p. 249

6 Ahmad Syahrizal, Peradilan Konstitusi, Suatu Studi tentang Adjudikasi Konstitusional Sebagai Mekanisme Penyelesaian Sengketa Normatif, Pradnya Paramita, Jakarta, 2006 p. 263.
} 
decision on the opinion of the DPR that the President and / or Vice President are alleged to have violated the law in the form of treason against the state, corruption, bribery, serious crimes others, or disgraceful acts, and / or no longer qualify as a President and / or Vice President as referred to in the 1945 Constitution. ${ }^{7}$

Article 7A states that "the President and / or Vice President may be dismissed during their term of office by the People's Consultative Assembly at the suggestion of the House of Representatives, both if they have been proven to have violated the law in the form of betrayal of the state, corruption, bribery, other serious crimes, or disgraceful acts or if it is proven that it no longer meets the requirements as President and / or Vice President."

The article contains provisions on the dismissal of the President and / or Vice President during his term of office (impeachment) based on legal reasons or other reasons, which are not political and multiple interpretations as happened in the previous era. With the formulation of the 1945 Constitution of the Republic of Indonesia which expressly and clearly regulates impeachment, only for reasons stated in the provisions of Article 7A only, a President and / or Vice President may be dismissed during his term of office. That can only be done after going through a constitutional process through the Constitutional Court and the DPR.

The role of the Constitutional Court emphasizes the operation of the rule of law. Decision of the Mahmakah of the Constitution is a legal decision based on mere legal considerations. The position of the Constitutional Court's decision becomes the reference / reference for the DPR regarding whether the proposal to dismiss the President and / or Vice President is forwarded or terminated.

Furthermore, in Article 7B paragraph (1) it is stated that "Proposals for dismissal of the President and / or Vice President can be submitted by the House of Representatives to the People's Consultative Assembly only by first submitting a request to the Constitutional Court to examine, hear and decide upon the opinion of the House of Representatives that the President and / or the Vice President has committed a violation of the law in the form of betrayal of the state, corruption, bribery, other serious criminal offenses, or misconduct; and / or opinions that the President and / or Vice President no longer qualify as President and / or Vice President."

In simple terms, the constitutional court has four authorities and one obligation which is mandated both by the 1945 Constitution of the Republic of Indonesia and the Constitutional Court Law. In article 24C paragraph (1) relating to the authority of the Constitutional Court outlines the final nature of the decision. As for the obligation of the constitutional court in deciding the opinion of the DPR in the termination of the President and / or Vice President in

7 Maruarar Siahaan, Hukum Acara Mahkamah Konstitusi Republik Indonesia,Sinar Grafika: Jakarta, 2012 p. 12 
Article 7B of the 1945 Constitution relating to article 24C paragraph (2) does not give the nature of the decision of the Constitutional Court.

The procedural guidelines for deciding the opinion of the House of Representatives regarding alleged violations by the President and / or Vice President are regulated in the Constitutional Court Regulation No. 21/2009 concerning Procedure Guidelines in Deciding the Opinion of the House of Representatives Regarding Alleged Violations by the President and / or Vice President. This PMK is a more technical regulation in the context of examining, adjudicating, and deciding cases related to dismissal within the term of office of the President and / or Vice President proposed by the House of Representatives. ${ }^{8}$ Related to the Constitutional Court's Decision regarding the opinion of the DPR in terms of dismissal of the President and / or Vice President in the PMK outlined legally and legally binding for the DPR as the party who filed the petition.

The formulation of PMK No. 21 of 2009 Article 19 paragraph (5) raises new legal issues concerning the material content and its position in the hierarchy of statutory regulations. From a brief description of the facts and legal issues that occur in the community, the importance of doing research related to the decision of the Constitutional Court related to the dismissal of the President, the authors feel compelled to do this research.

\section{B. PROBLEM}

Based on the background of the problems that have been described, a formulation of the problem can be formulated, namely: what is the legis ratio Ruling of the Constitutional Court No. 21/2009 Article 19 Paragraph (5) Concerning the final nature and the strength of the law regarding the decision of the Constitutional Court in terms of Impeachment?

\section{RESEARCH METHODS}

This research is a type of normative legal research (normative legal research). Normative research is a process to find the rule of law, legal principles, and legal doctrines to address the legal issues at hand. The research approach is the statutory approach (statue approach), conceptual approach (conceptual approach). The legal material from this study consisted of primary legal materials, secondary legal materials and tertiary legal materials. The source of legal research material was obtained through the Central Library of Brawijaya University in Malang, the Center for Documentation and Legal Information (PDIH) at the Faculty of Law of the University of Brawijaya and the Central Public Library of Malang City. The technique of gathering legal material in this research is through library research and

${ }^{8}$ Bambang Sutiyoso, 2010, Reformasi Keadilan dan Penegakkan Hukum di Indonesia, Yogyakarta: UII Press, h. 151. 
internet access. The analysis technique used is analytical analysis with systematic interpretation and grammatical interpretation.

\section{RESULT AND DISCUSSION}

\section{Constitutional Court Regulation Ratio No. 21 of 2009 Article 19 paragraph (5) concerning Impeachment}

Ratio legis of the rule of law contain an explanation of why a rule of law was issued or made. Legis ratio is the broadest basis for the birth of a rule of law. Besides that legis ratio is the reason for the birth of legal regulations, or legal regulations. ${ }^{9}$ So that the legis ratio as the basis for the birth of legislation and the reason or general purpose of the birth of legislation. To analyze the Constitutional Court Regulation Article 19 paragraph (5) of the Constitutional Court Regulation No. 21 of 2009 concerning Impeachment of the President, in advance of his position in the hierarchy of legislation. This is intended to determine whether the regulation has binding legal force in certain legal conditions.

The hierarchy or sequence of laws and regulations in Indonesia is contained in Article 7 paragraph (1) of Law Number 12 of 2011 concerning the Formation of Regulations that read:

Types and hierarchy of statutory regulations consist of:

a. The 1945 Constitution of the Republic of Indonesia;

b. Decree of the People's Consultative Assembly;

c. Government Act / Regulation in Lieu of Law;

d. Government regulations;

e. Presidential decree;

f. Provincial Regional Regulations; and

g. Regency / City Regulations.

There are 7 hierarchies or order in Article 7 paragraph (1) of Law 12/2011 which consists of the 1945 Constitution of the Republic of Indonesia to the District / City Regulations. In addition to the types of statutory regulations referred to in Article 7 paragraph (1) of Law 12/2011 includes regulations stipulated by the People's Consultative Assembly, the House of Representatives, the Regional Representative Council, the Supreme Court, the Constitutional Court, the Supreme Audit Board, the Judicial Commission, the Bank Indonesia, Ministers, bodies, institutions, or commissions of the same level formed by Law or Government by order of the Law, Provincial Regional Representative Council, Governor, Regency / City Regional Representative Council, Regent / Mayor, Village Head or the like one level.

\footnotetext{
${ }^{9}$ Satjipto Rahardjo, Ilmu Hukum, (Bandung: Alumni Bandung, 1986), hal. 89.
} 
These laws and regulations (other than those mentioned in Article 7 paragraph (1) of Law 12/2011) are recognized and have binding legal force as long as they are ordered by higher laws or are formed based on authority. The Constitutional Court, is given authority according to Article 86 of Law Number 24 Year 2003 concerning the Constitutional Court to be able to further regulate matters needed for the smooth implementation of its duties and authorities. One example is the Constitutional Court Regulation Number 06 / PMK / 2005 concerning Guidelines for Procedure in Judicial Review.

Thus the rules established by the Constitutional Court constitute other laws and regulations outside the legislation contained in the hierarchy of statutory regulations as mentioned in Article 7 paragraph (1) of Law 12/2011. That is, Constitutional Court Regulations are also types of legislation and their existence is recognized and has binding legal force insofar as it is ordered by higher statutory regulations or formed based on authority.

After searching for these legal documents through a variety of ways the author did not find an academic paper or minutes of session Article 19 paragraph (5) of the Constitutional Court Regulation No. 21 of 2009 concerning the President's Impeachment. According to the expert staff of the Constitutional Court PMK (Constitutional Court Rule) does not have an academic paper or minutes of hearings. The foundation of the PMK (Constitutional Court Rule) is made to regulate matters needed in the smooth proceedings of the Constitutional Court in accordance with the authorities.

In the absence of academic texts, Constitutional Court Regulation No. 21 of 2009 concerning the President's Impeachment, researchers analyzed the legis ratios of the considerations and the legal basis of Constitutional Court Regulation No. 21 of 2009. Following is the presentation of the consideration and legal basis of PMK No. 21 of 2009; ${ }^{10}$

Consider:

a. That the constitutional court is obliged to give a decision on the opinion of the House of Representatives regarding alleged violations by the President and / or Vice President according to the Basic Law;

b. That the provisions of the procedural law to carry out the obligation referred to in letter a are incomplete;

c. That the Constitutional Court has the authority to regulate matters that are necessary for the smooth implementation of their duties and authorities;

$d$. Whereas based on considerations $a, b$ and $c$, it is necessary to stipulate Constitutional Court regulations regarding the procedural guidelines for deciding the opinion of the DPR regarding alleged violations by the President and / or Vice President.

Remembering:

\footnotetext{
${ }^{10}$ Peraturan Mahkamah Konstitusi No. 21 Tahun 2009 Tentang Impeachment Presiden hal 1
} 
a. Article 7B and Article 24C paragraph (2) of the 1945 Constitution of the Republic of Indonesia;

b. Law Number 24 of 2003 concerning the Constitutional Court (State Gazette of the Republic of Indonesia of 2003 Number 98, Supplement to the State Gazette of the Republic of Indonesia Number 4316).

A brief description of the main background and reasons for making the legislation is part of the Preamble or weighing section. ${ }^{11}$ In the preliminary thought there are 3 (three) elements contained within it including philosophical, sociological, and juridical elements which form the basis and reasons for its formation which are placed sequentially from philosophical, sociological, and juridical.

If the weighing section contains more than one point, each point is formulated in a series of sentences which constitute a unity of understanding. Each point begins with using the letters of the alphabet, and formulated in a sentence that begins with the word "that" and ends with a semicolon ";"12

The following section Considering in the Constitutional Court Regulation No. 21 of 2009 which outlines and describes the philosophical, sociological and juridical elements that are the background of PMK making:

Consider :

a. That the constitutional court is obliged to give a decision on the opinion of the House of Representatives regarding alleged violations by the President and / or Vice President according to the Basic Law;

b. That the provisions of the procedural law to carry out the obligation referred to in letter a are incomplete;

c. Whereas the Constitutional Court has the authority to regulate matters required for the smooth implementation of its duties and authorities;

$d$. Whereas based on considerations $a, b$ and $c$, it is necessary to stipulate Constitutional Court regulations regarding the procedural guidelines for deciding the opinion of the DPR regarding alleged violations by the President and / or Vice President

Based on the considerations above, the researcher analyzes and interprets. As follows:

a. Letter a in consideration of Constitutional Court Regulation No. 2009 reflects the sociological elements that are considered and the reasons for their formation. This is marked by the sentence "That the constitutional court must give a decision on the opinion of the House of Representatives regarding alleged violations by the President and / or Vice President". The sentence shows aspects of compliance with laws and regulations for

11 Maria Farida Indrati S. Ilmu Perundang-Undangan: Proses dan Teknik Pembentukannya, Yogyakarta: Kanisius, 2007, p 108.

${ }^{12}$ Ibid. p. 109 
the operation of the legal system in Indonesia in accordance with the mandate of the 1945 Constitution of the Republic of Indonesia.

b. Letter b in consideration of the Constitutional Court Regulation No. 21 of 2009 reflects the judicial element that explains that the regulations established to overcome legal problems in the form of filling the legal vacuum by considering existing rules (ius constitutum), which will be changed, or which will be revoked to ensure legal certainty and taste community justice. According to the grammatical interpretation of the term "incomplete" as stated in the consensus letter (b) the PMK is interpreted in language as "legal vacuum" or "incomplete law"

c. Letter c in consideration of the Constitutional Court Regulation No. 21 of 2009 also reflects the judicial element because it is related to the regulation established to fill the legal vacuum.

d. Letter d explains "That based on the considerations of letters a, b and c, it is necessary to stipulate the Constitutional Court rules ..." according to a systematic interpretation that the rules regarding impeachment in the statutory provisions that exist in the entire legal system experience emptiness or inability. norms so that through the letter $d$ in the preamble interpreted it is necessary to make regulations to fill the void of norms for the sake of smooth proceedings in the institution of the Constitutional Court.

Part remembering or known as the legal basis is a juridical basis for the formation of legislation. ${ }^{13}$ The basic part of the law or the remembrance section, at least contains the basis of the authority to form laws and regulations, and the laws and regulations that instruct the establishment of these laws and regulations.

In the same book, regulations that are on the same level and are above the rules to be formed are used as a legal basis or a remembrance section. In addition to these regulations, which are regulations that will be formed (still in draft form), rules that have been invalidated (revoked) will not be included in the recall section. ${ }^{14}$ The preparation of the memorandum in accordance with the hierarchy or order of the regulations in Article 7 of Law No. 12/2011, and in accordance with the chronology or date of the legislature or regulation. ${ }^{15}$

The recall section which is the basis of the article in the 1945 Constitution of the Republic of Indonesia was written mentioning the related article or several articles. The phrase "1945 Constitution of the Republic of Indonesia" is written after the mention of the last chapter and the second letter " $\mathrm{u}$ " is written in capital letters. ${ }^{16}$

\footnotetext{
${ }^{13}$ Ibid. p. 110

${ }^{14}$ Ibid. p. 111

${ }^{15}$ Tri Jata Ayu Pramesti, Arti 'Menimbang' dan 'Mengingat' Dalam Peraturan Perundang-Undangan, Hukumonline.com, https://www.hukumonline.com/klinik/detail/ulasan/lt571458c928b51/arti-menimbang-danmengingat-dalam-peraturan-perundang-undangan(diakses pada tanggal 3 Januari 2018)

16 Maria Farida Indrati S dalam Tri Jata Ayu Pramesti, Arti 'Menimbang' dan 'Mengingat' Dalam Peraturan Perundang-Undangan, Hukumonline.com,
} 
Remembering:

a. Article 7B and Article 24C paragraph (2) of the 1945 Constitution of the Republic of Indonesia;

b. Law Number 24 of 2003 concerning the Constitutional Court (State Gazette of the Republic of Indonesia of 2003 Number 98, Supplement to the State Gazette of the Republic of Indonesia Number 4316)

Based on a systematic interpretation of the final nature and binding of the decision of the Impeachmet to the laws and regulations, there is a legal vacuum. The following explanation is in accordance with the legal content of PMK No. 21 of 2009:

a. Article 7B of the 1945 Constitution of the Republic of Indonesia

Analysis: The MPR is the last institution to determine the status of the President and / Vice President after the DPR and Constitutional Court processes are completed. This means that even if the Constitutional Court states that the President and / Vice President are proven to have violated the law, or have committed a disgraceful act, or have no longer fulfilled its requirements, the President and / Vice President will not be automatically dismissed immediately.

b. Simply put, the constitutional court has four authorities and one obligation which is mandated by both the 1945 Constitution and the Constitutional Court Law. In article 24C paragraph (1) relating to the authority of the Constitutional Court outlines the final nature of the decision. As for the obligation of the constitutional court in deciding the opinion of the DPR in the termination of the President and / or Vice President in Article 7B of the 1945 Constitution relating to article 24C paragraph (2) does not give the nature of the decision of the Constitutional Court.

c. Analysis: The formulation of the nature of the Constitutional Court's decision textually experiences a separation between the four powers referred to in article 24C paragraph (1) of the 1945 Constitution of the Republic of Indonesia with the provisions mentioned in article paragraph (2) by not attaching or repeating the final and final decision of the first level raises a variety of problems and interpretations.

\section{E. CONCLUSION}

The conclusions of this study as the compilation of the description above it can be concluded that the ratio legis of the Constitutional Court Decision Number 21 of 2009 relating to the decision of the Impeachment is to fill the void of the final nature setting and the binding of the impeachment decision of the Constitutional Court which previously did not exist in existing legislation.

https://www.hukumonline.com/klinik/detail/ulasan/lt571458c928b51/arti-menimbang-dan-mengingat-dalamperaturan-perundang-undangan (diakses pada tanggal 3 Januari 2018) 


\section{REFERENCES}

Ahmad Syahrizal, Peradilan Konstitusi, Suatu Studi tentang Adjudikasi Konstitusional Sebagai Mekanisme Penyelesaian Sengketa Normatif, Pradnya Paramita, Jakarta, 2006

Bambang Sutiyoso, Reformasi Keadilan dan Penegakkan Hukum di Indonesia, UII Press, Yogyakarta: 2010

Klinik hukumonline.com, Mekanisme Pemberhentian Presiden, (Online), https://www.hukumonline.com/klinik/detail/lt5821445b3d1a4/mekanismepemberhentian-presiden (diakses pada tanggal 3 Februari 2019).

Mahfud MD, Hukum dan Pilar-Pilar Demokrasi, Gama Media, Yogyakarta, 1999).

Maria Farida Indrati S dalam Tri Jata Ayu Pramesti, Arti 'Menimbang' dan 'Mengingat' Dalam Peraturan PerundangUndangan,Hukumonline.com, https://www.hukumonline.com/klinik/detail/ulasan/lt57 1458c928b51/arti-menimbang-dan-mengingat-dalam-peraturan-perundangundangan (diakses pada tanggal 3 Januari 2018)

Maria Farida Indrati S, Ilmu Perundang-undangan Proses dan Teknik Pembentukannya. Kanisius, Yogyakarta: 2007.

Maruarar Siahaan, Hukum Acara Mahkamah Konstitusi Republik Indonesia, Sinar Grafika: Jakarta, 2012.

Miftakhul Huda, "Ultra Petita" dalam Pengujian Undang-Undang, (Online) dalam Jurnal Konstitusi Volume 4 Nomor 3, Mahkamah Konstitusi Republik Indonesia, Jakarta, September 2007

Nanang Sri Darmadi, Kedudukan Dan Wewenang Mahkamah Konstitusi Dalam Sistem Hukum Ketatanegaraan Indonesia, Jurnal Hukum Vol XXVI, No. 2, Agustus 2011

Peraturan Mahkamah Konstitusi Nomor 21 Tahun 2009 Tentang Impeachment

Satjipto Rahardjo, Ilmu Hukum, Alumni Bandung, Bandung: 1986,

Sholahuddin Al-Fatih, Model Pengujian Peraturan Perundang-undangan Satu Atap Melalui Mahkamah Konstitusi, Legality: Jurnal Ilmiah Hukum, Volume 25 Nomor 2, 2017

Tri Jata Ayu Pramesti, Arti 'Menimbang' dan 'Mengingat' Dalam Peraturan PerundangUndangan, Hukumonline.com,

https://www.hukumonline.com/klinik/detail/ulasan/lt571458c928b51/arti-menimbangdan-mengingat-dalam-peraturan-perundang-undangan (diakses pada tanggal 3 Januari 2018)

Undang-Undang Dasar Negara Repulik Indonesia Tahun 1945

Undang-Undang No 12 Tahun 2011 Tentang Pembentukan Peraturan Perundang-Undangan

Undang-Undang No. 24 Tahun 2003 Tentang Mahkamah Konstitusi 